\title{
Technology and Products Supporting E-learning by Knowledge Management - A Review
}

\author{
http://dx.doi.org/10.3991/ijet.v9i4.3625 \\ Ying Wang \\ ${ }^{1}$ Beijing Information Science \& Technology University, Beijing, China
}

\begin{abstract}
Knowledge management is supported by many strategies such as business intelligence, collaboration, document management and e-learning. With the development of modern information technology and the increases of demand for building and maintaining dynamic capabilities, $E$ learning has played more and more important role of all the technologies in the supporting knowledge management. A successful e-learning system is supported by many critical success factors and technology has become the key factor among these factors. Consequently, the review of basic technologies and corresponding products that support elearning will be in favor of further study on e-learning. From perspective of knowledge management, this paper makes a review about the relationship between e-learning and knowledge management and advanced technologies and corresponding products that support the design and operation of e-learning system. At the end of this paper, we analyze the main trends of the development direction of elearning technology.
\end{abstract}

Keywords-e-learning; knowledge management; product; technology

\section{INTRODUCTION}

Knowledge Management, is nothing new, but instead is newly practices and has become the most prevalence method to enhance the learning capabilities of organizations and organizational members [1]. Many technologies can be used to support knowledge management system, such as business intelligence, collaboration and e-learning. Ee-learning has played more and more important role of all the technologies in the supporting process of knowledge management. Thus, it is urgent for researchers to pay more attention to the theory and technologies development of e-learning.

E-learning system as a just-in-time training delivery system need much help from modern techniques and tools to accomplish the delivery of information. Researchers proposed many advanced technologies and products to support the design and operation of e-learning. So this paper tries to make a literature review of these technologies and corresponding products from the perspective of knowledge management. Based on the review, we put forward the main trends of the development direction of elearning technology.

\section{THE DEFINITION OF E-LEARNING}

The concept of e-learning is proposed on the basis of distance learning that is a broadcast of lectures to distant locations through video presentations [2]. Learning is the retention and transfer of knowledge to new and different situations. Of all the educational technologies that have exhibited great potential, e-learning appears to be the most promising[3]. The definition of e-learning given by the NCSA e-Learning group is that "e-learning is the acquisition and use of knowledge distributed and facilitated primarily by electronic means[4]. The basic rule of elearning can be understand as freedom from the restrictions of place and time[5]. P.M. Senge defined elearning as "he uses Internet technologies to deliver a broad array of solutions that enhance knowledge and performance" [6]. The Conference Board of Canada's workplace e-learning report provides: "E-learning uses information and communications technologies (ICTs) to deliver content (learning, knowledge and skills) on a one-way [asynchronous] or two-way [synchronous] basis"[7]. Rosemary defined e-learning as a revolutionary way to empower a workforce with the skills and knowledge it needs to turn change to an advantage [8].

From the arrangement of the definition of e-learning, we can get the characteristics of e-learning by summarizing above opinions:

- E-learning is a learning activity mainly based on internet.

- Information spreads in the form of network courses.

- Worldwide distribution and sharing of learning resource.

- Virtual study environment.

- Variety of the study way.

- $\quad$ Flexibility of study (anytime, anywhere).

The natural characteristics of e-learning are showed in figure1.

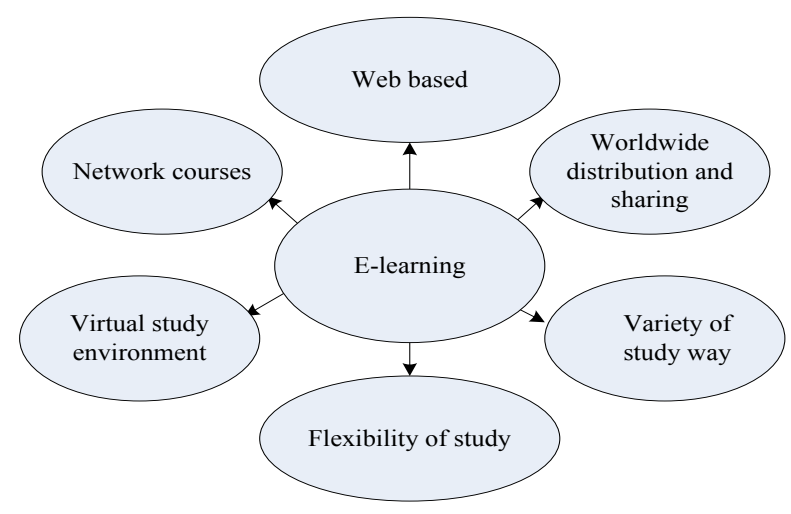

Figure 1. Characteristics of e-learning 


\section{SHORT PAPER}

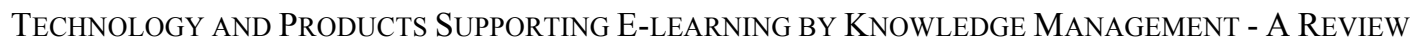

E-learning system can be described as a Web-based system that is designed to support delivery and processing of instant information of organization.

\section{RELATIONSHIP BETWEEN KNOWLEDGE MANAGEMENT AND E-LEARNING}

E-learning is a novel and flexible learning style which can enhance the learning and innovation capability of organization and organizational members. To study and review technologies and tools supporting to e-learning system, we must first find out the guide theory of e-learning system. With the guide theory we can get the basic direction for our further study. Knowledge management and elearning are two words with closed relationship. A lot of researches have showed the relationship between Knowledge management and e-learning.

E-learning has become a vital step in the development of Knowledge Management Systems. Based on Neumann and Schupp's research of e-learning and cooperation as elements of knowledge management, e-learning makes an important contribution to accessibility, transparency and maintenance knowledge [9]. Jing Luan takes e-learning as one of the basic technologies that supporting knowledge management system [10]. On the other hand, performance of knowledge management has great influence on elearning system. Erla Morales proposed that knowledge management and e-learning are closely related because elearning users need a suitable knowledge management that can help them to obtain the kind of content they need together with as correct and complete information as possible[11].

From the summery of above researches we can conclude that knowledge management and e-learning have closed relationship indeed. Knowledge management is the premise and operational platform of e-learning system and the e-learning is the key technology and tool supporting knowledge management. So the design and operation of elearning system should oriented by knowledge management. Knowledge management oriented e-learning has become the effective tool that transforms tacit knowledge information into explicit knowledge. With the knowledge management oriented e-learning system, organizations can accomplish knowledge and information delivery in or among organizations. This kind of e-learning system organization can promote the efficiency of knowledge communication. So this paper summarizes the technologies, tools and products supporting e-learning system from perspective of knowledge management. Figure 2 shows the relationship between knowledge management and elearning system.

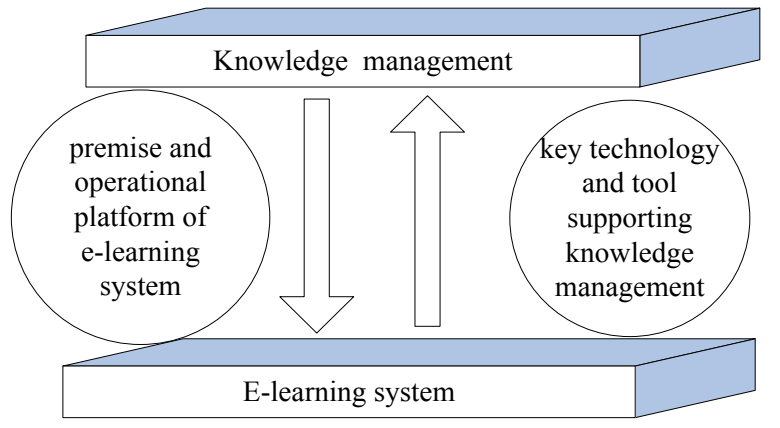

Figure 2. Relationships between knowledge management and elearning system

\section{LITERATURE REVIEW OF TECHNOLOGY AND PRODUCT SUPPORTING E-LEARNING SYSTEM}

\section{A. Review of the Development of Technology Supporting E-Learning System}

A successful e-learning system is supported by several critical success factors (CSFs) and technology has become the key factor among the CSFs. Different scholars put forward different information technologies to design and support e-learning system. There technologies enhance the learning efficiency and develop the knowledge management of organization. We summarize the basic technologies that playing important role in e-learning system design and operation in Table 1.

TABLE I.

DEVELOPMENT OF INFORMATION TECHNOLOGIES OF E-LEARNING

\begin{tabular}{|c|c|c|}
\hline Technology & Presenter & $\begin{array}{c}\text { Proposed } \\
\text { Year }\end{array}$ \\
\hline DHTML & Pellegrino, Goldman[12] & 1999 \\
\hline VRML & Janet Johns[13] & 2000 \\
\hline Portals & Brandon Hall[14] & 2000 \\
\hline KnowledgeTree & $\begin{array}{c}\text { Peter Brusilovsky, Hemanta } \\
\text { Nijhavan[15] }\end{array}$ & 2002 \\
\hline LiveNet & Quang Vinh Nguyen[16] & 2004 \\
\hline Ajax & Jesse James Garrett[17] & 2005 \\
\hline E-dap & Bonastre[18] & 2005 \\
\hline $\begin{array}{c}\text { Central LASAR } \\
\text { system }\end{array}$ & Andre Luiz[19] & 2007 \\
\hline CAT & Mu-Jung Huang[20] & 2007 \\
\hline WIFI & J.R.Corbeil, M.E.Valdes[21] & 2008 \\
\hline
\end{tabular}

From Table 1we can see that the technologies developed for e-learning system are mainly information technologies. Information technologies have become the most important technology for the development and operation of e-learning system. How to make full use of these information technologies for the establishment and operation of e-learning system will become one of the most important strategies for all organizations that engaged in the promotion of learning capability.

\section{B. Review of Products Supporting E-Learning System}

Successful operation of an e-learning system needs products to transfer knowledge to members of organization. There are many products supporting e-learning and Table 2 captures main examples.

The products proposed by different scholars to support e-learning system are mainly developed on the basis of information technologies. The function of these products to e-learning system is similar as the function of software to computer. These products make the delivery and share of knowledge in organization come true.

\section{THE TECHNOLOGY DEVELOPMENT TRENDS OF E-LEARNING SYSTEM}

The review brings us a scene of the actuality of elearning theory and application. Because of the fast change and complication of market environment, any changes of a slight factor may become the important reason of success or failure of e-learning system. To promote learning efficiency and learning ability of organization, we must consider every factor that supports the operation 
TABLE II.

PRODUCTS SUPPORTING E-LEARNING SYSTEM

\begin{tabular}{|c|c|}
\hline Product & Description \\
\hline $\begin{array}{l}\text { Linux } \\
\text { operating } \\
\text { system }\end{array}$ & $\begin{array}{l}\text { The product is object-oriented projected to be easily } \\
\text { customized for each type of Linux system installation. } \\
\text { This product was made using the facilities of IDE } \\
\text { Delphi.[22] }\end{array}$ \\
\hline $\begin{array}{l}\text { e-Learning } \\
\text { Suite }\end{array}$ & $\begin{array}{l}\text { Mainly developed for training sales workers, the } \\
\text { eLearning suite, consisting of e-Training and Siebel } \\
\text { Distance Learning, provides automated content man- } \\
\text { agement, methods of measuring learning, and course } \\
\text { content delivery.[22] }\end{array}$ \\
\hline $\begin{array}{l}\text { Human } \\
\text { Capital } \\
\text { Management } \\
\text { Suite }\end{array}$ & $\begin{array}{l}\text { The suite includes trademark KP, Performance, KP } \\
\text { Learning, and KP Content. Learners can create custom- } \\
\text { ized blended online learning curricula. Products test } \\
\text { and track learner progress and activities.[23] }\end{array}$ \\
\hline TrainNet & $\begin{array}{l}\text { Consisting of five modules, this virtual and integrated } \\
\text { on-line learning system works for a variety of delivery } \\
\text { modalities. It integrates full-screen video with live } \\
\text { interaction, using audio conferencing, synchronized } \\
\text { Web content, application sharing, embedded email, and } \\
\text { whiteboard and Q\&A features.[23] }\end{array}$ \\
\hline $\begin{array}{l}\text { LMS } \\
\text { (Learning } \\
\text { Management } \\
\text { System) }\end{array}$ & $\begin{array}{l}\text { Learning Management Systems (LMS) is the starting } \\
\text { point (or critical component) of any e-learning or } \\
\text { blended learning program. LMS offers its greatest } \\
\text { value to the organization by providing a means to } \\
\text { sequence content and create a manageable structure for } \\
\text { instructors/administration staff.[23] }\end{array}$ \\
\hline $\begin{array}{l}\text { Vuepoint } \\
\text { Learning } \\
\text { System } \\
3.0\end{array}$ & $\begin{array}{l}\text { Four modules make up this e-learning and content } \\
\text { management system: a Web-based evaluation, teach- } \\
\text { ing, and research tool; a student testing and course } \\
\text { tracking program; a template-based content creator; } \\
\text { and an off-line viewer for asynchronous learning.[10] }\end{array}$ \\
\hline
\end{tabular}

of e-learning system and integrate synthetically many kinds of technologies and means. By integrating different kinds of technologies, every key element in the e-learning system will coordinate and will give play to its greatest benefit [24]. So integration of different information technologies and integration of information technology with other technologies will be basic direction of e-leaning technology development.

\section{A. Development of Technology Integrating Knowledge Management with E-Learning System}

Although e-learning system and knowledge management have their unique characteristics, the relationship between them has become more and more closed. Many scholars have found that the emphasis on e-learning has become shifting to "performance support" with the integration of Knowledge Management capabilities. With the highly competitive and dynamic environment, the integration of knowledge and e-learning system has become the critical requirement of improving the learning and innovation capability of organization. E-learning users need a suitable knowledge management system to obtain correct and complete information they need. Knowledge management system needs an advanced e-learning system to help it realize the effective transmission of knowledge. Therefore, the technologies and products that integrate knowledge management and e-learning will be the urgent need for the development of e-learning.

\section{B. Development of Collaborative E-Learning Technologies}

Collaborative technologies will improve the operability of e-learning system and accelerate the generalization of e-learning system. So a great many owners turn their fo- cus on how to build up a more perfect learning environment for collaborative e-learning. Collaborative e-learning includes man-machine interactions and man-man interactions. Compared with the development of man-machine interaction technology, man-man interactions need more rapid development. Because of the defects of e-learning system, such as lack of interpersonal communication, baldness and aridity, interpersonal communication has become an important direction for e-learning. Collaborative technologies and products that improve interpersonal communication in e-learning system will be one basic trend of the development of e-learning.

\section{Combination of Technical Domination and Technical Assistant}

Technical domination and technical assistant are two basic views about the development direction of e-learning since the birth of e-learning. In the term of the nature of elearning, an effective e-learning is not decided by whether it is a technical domination or a technical assistant. In terms of characteristics of learning content, the e-learning platform of technical domination more suits for explicit, cognitive and technical knowledge, while the e-learning platform of technical assistant more suits for an academic or soft technology one. A learner no matter where he is-in an enterprise or college-needs both of these two learning modes. Thus a platform that combine the views of technical domination and technical assistant is a promising one that accords with the develop trend of e-learning platform.

\section{CONCLUSIONS}

From perspective of knowledge management of organization, this paper makes a review about e-learning system, especially on the definition of e-learning and the relation between e-learning and knowledge management. Besides, this paper makes a review about advanced technologies and products that support the design and operation of elearning system. With these reviews of e-learning, we find that more theory about technology and corresponding products is needed to guide the design, delivery, and implementation of e-learning. At the end of this paper, we analyze the main trends of the development direction of elearning technology. With the development of information technology, we believe that more advanced technologies and more effective products that support e-learning will be put forward. E-learning will have a very promising future in the new millennium.

\section{REFERENCES}

[1] M. T. Hansen, N. Nohria and T. Tierney, "What's your strategy for managing knowledge? "Harvard Business Review, 2002,vol.77(2), pp. 106-116.

[2] M.Gotschall. "E-learning strategies for executive education and corporate training”. Fortune, 2007,vol.141 (10), pp. 5-59.

[3] Shu-Sheng Liaw, Hsiu-Mei Huang, Gwo-Dong Chen. "An activity-theoretical approach to investigate learners' factors toward elearning systems". Computers in Human Behavior, 2011, vol.23, pp. 1906-1920. http://dx.doi.org/10.1016/j.chb.2006.02.002

[4] L.Tim Wentling, Consuelo Waight, James Gallaher ,Jason La Fleur, Christine Wang, Alaina Kanfer. "E-learning - A Review of Literature.",Knowledge and Learning Systems Group, NCSA, 2010.

[5] Heidi Schweizer. "E-learning in business". Journal of management education, 2009, vol. 28(6), pp. 674-692. http://dx.doi.org/10.1177/1052562903252658 


\section{SHORT PAPER}

\section{Technology and Products SupPorting E-LEARning By KNOWLEdGe MANAGEMENT - A REVIEW}

[6] P.M. Senge, "The Fifth Discipline: the Art and Practice of the Learning Organization". DoubleDay Currency, New York, 2000.

[7] Conference Board of Canada, "E-Learning for the Workplace: Creating Canada's lifelong learners". available at: www. conferenceboard. ca/elearning, (accessed 28 October 2003).

[8] M.E. Jennex, "Case studies in knowledge management". Idea Group Publishing, pp. 33-45, 2009.

[9] H.Neumann, W.Schupp. "E-Learning and cooperation as elements of knowledge management". Stahl Und Eisen, 2003, vol.123(9), pp.81-84.

[10] Jing Luan, M.Andreea Serban. "Technologies, products, and models supporting knowledge management". New Directions for Institutional Research, 2012, vol.113, pp. 85-104.

[11] Erla Morales. "Knowledge Management for E-learning based on Learning Objects: A Qualitative Focus". ITHET 6th Annual International Conference, Session F4B,2005.

[12] J. W. Pellegrino, S. R. Goldman. "The new languages". Training and Development. 1999, vol.53(8), pp. 35-46.

[13] T. Barron. "The future of digital learning". E-learning, 2010, vol.1(2), pp. 46-57.

[14] T. L. Wentling, C. Waight, J. Gallaher, J. L. Fleur, C. Wang, A. Kanfer. "E-learning-A Review of Literature". Knowledge and Learning Systems Group. 2010, vol.6(9), pp.37-51.

[15] P. Brusilovsky, H. Nijhavan. "A framework for adaptive eLearning based on distributed re-usable learning activities". Proceeding of World Conference on E-Learning (AACE, Canada), 2012, pp. 154-161.

[16] Q. V. Nguyen, M. Huang, I. Hawryszkiewycz. "A new visualization approach for supporting knowledge management and collaboration in e-Learning". Proceedings of the Eighth International Conference on Information Visualisation(Computer Society, London, England), 2011, pp.693-700.
[17] J. J. Garrett. Ajax: A New Approach to Web Applications, Adaptive Path (2005). http://www.35dx.com/html/web/1/web386.html (Accessed July 8, 2007).

[18] O. M. Bonastre, A. P. Benavent, M. A. Ortuno. "E-dap: An elearning tool for Managing, Distributing and Capturing Knowledge". ITHET 6th Annual International Conference, eds. J. Dolio(IEEE, Dominican Republic), 2008, pp.S3B11-15.

[19] A. L. M. de Oliveira, C. A. Schneider. "Metrology on-the-job elearning through remote services". Measurement. 2007, vol. 40(7), pp. 183-191. http://dx.doi.org/10.1016/j.measurement.2006.07.004

[20] M. Huang, H. Huang, M. Chen. "Constructing a personalized elearning system based on genetic algorithm and case-based reasoning approach". Expert Systems with Applications. 2011, vol.33(5), pp.551-564.

[21] J.R.Corbeil, M.E.Valdes. "Are you ready for mobile learing?”Educause Quarterly.2008,vol.30(2),pp. 718-727.

[22] Byron Marshall, Convergence of knowledge management and elearning: the GetSmart experience, Proceedings of the 2003 Joint Conference on Digital Libraries. 2013. IEEE.

[23] George Siemens. "Learning Management Systems: The wrong place to start learning". http: // www. elearnspace. Org / Articles / lms. htm, Vol.22, 2011

[24] S. Liu, G. Xiang. "Research on the Integration of Knowledge Management and E-Learning". Modern Educational Technology. 2008, vol.14(4), pp. 10-14.

\section{AUTHORS}

Ying Wang. Author is with the School of Economics \& Management, Beijing Information Science \& Technology University, Beijing, CO 15201167162 China (e-mail: yeaishuijiao@126.com).

Submitted 06 March 2014. Published as resubmitted by the author 14 June 2014. 